International Business Management 13 (9): 415-422, 2019

ISSN: $1993-5250$

(C) Medwell Journals, 2019

\title{
Poverty Status Assessment Among Small Scale Farm Households Microcredit Users in Ekiti State Nigeria
}

\author{
${ }^{1}$ F.M. Oluwatusin, ${ }^{1}$ F.O. Osundare, ${ }^{1}$ S.O.W. Toluwase, ${ }^{1}$ A.O. Adekunmi, \\ ${ }^{1}$ A. Ajiboye and ${ }^{2}$ O.A. Aturamu \\ ${ }^{1}$ Department of Agricultural Economics and Extension Services, Ekiti State University, \\ P.M.B 5363, Ado-Ekiti, Nigeria \\ ${ }^{2}$ Department of Agricultural Education, College of Education, Ikere-Ekiti, Nigeria
}

\begin{abstract}
The study was embarked upon to assess the poverty status among small scale farm household's micro credit users in Ekiti state. Specifically, the study described the socio economic characteristics of the respondents identified the poverty status of the respondents and determined the factors affecting the poverty status of the small scale farm household's micro credit users in Ekiti state. A well-structured questionnaire was used to elicit information from 150 respondents selected through a multi-stage sampling procedure. The data were analyzed with the use of descriptive statistics, Foster-Greer-Thorbecke (FGT) indices and multivariate probit model. It was revealed that most of the respondents were within the active age range with mean age of 46 years, mostly male (78.67\%), married ( $88 \%$ ) with average household size of 6 persons. The majority, $85.33 \%$ had access to formal education while the average farm size was 2 ha with average farm household income of N224,846.00 per annum. The average farming experience was 18 years and the main source of micro credit to the majority $(71.33 \%)$ of the respondents was micro credit agency in the state. The average loan applied for and granted was $\mathrm{N} 427,950$ but N161,755 was the average amount spent on farming activities. The main challenge encountered in accessing micro credit facilities by $48 \%$ (most) of the respondents was lack of collateral security. In determining the poverty status among the respondents, Mean Per Capita Household Annual Income (MPCHHAI) of N45,905 was used as poverty line. It was revealed that $73.33 \%$ of the respondents were poor while the main factors affecting the poverty status of the respondents were sex, age, educational level, household size, membership of socio-economic organization, household income and amount of micro credit collected. It was recommended that the size of micro credit given to the farmers by micro credit agency should be improved upon and diversion of micro credit meant for agricultural production should be discouraged in order to boost agricultural production and alleviate poverty among the small scale farmers.
\end{abstract}

Key words: Micro credit, poverty, small scale, farmers, households

\section{INTRODUCTION}

Nigeria, the giant of Africa with the total land mass of $923,768 \mathrm{~km}^{2}$ is endowed with vast natural resources such as; 960 million ha of coastline and ecological diversity, 68 million ha of arable land, 37 million ha of natural forest and rangeland and 12 million ha of fresh resources. In spite of these resource's endowment, the productivity of agriculture in Nigeria is still low. But the importance of agriculture to Nigerian economy cannot be over emphasized. The distribution of Gross Domestic Product (GDP) across economic sectors in 2018 shows that agriculture contributed around $21.2 \%$ to Nigeria's GDP (SC., 2019). In addition to providing employment opportunities, agriculture also provides food and raw materials to very large percentage of the populace. It has been documented that over $70 \%$ of the population with small and scattered holdings are involved in agricultural activities. Anderson et al., (2017) observed that about $80 \%$ of farmers in Nigeria operate on small scale with $<5$ ha of farm land and produce $99 \%$ of the country agricultural outputs.

Despite the contributions of these small holders to economic development, the majority are still wallowing in abject poverty. This is so because previous investments and initiatives to agricultural sector such as the Anchor Borrowers scheme, the Nigeria Investment Risk Sharing and Lending Scheme (NIRSAL) among others are not properly directed to agricultural sector and therefore have not fully achieved their aims of creating impact on small scale farmers. Also the farmers are poor because most of them, still use very simple implements such as hoes and cutlasses have no

Corresponding Author: F.M. Oluwatusin, Department of Agricultural Economics and Extension Services, Ekiti State University, P.M.B 5363, Ado-Ekiti, Nigeria 
access to inorganic fertilizers are faced with low yields per unit area and still cultivate mainly food crops such as maize, cassava, yam, fruits and vegetables.

According to the World Bank (2004), poverty is multidimensional and it includes inability to acquire the basic goods and services necessary for survival, low incomes, low levels of education and health, poor access to potable water and sanitation, insecurity and not having enough capacity to feed and clothe the family. It has been reported that majority of those that are poor in Sub-Sahara African are small scale farmers. Reports have shown that Nigeria is now having the largest number of people living in extreme poverty (living on $<\$ 1.90$ a day) all over the world. About $46.4 \%$ of her estimated 195.6 million total population now live in extreme poverty while over $70 \%$ of the population is classified as poor (Solomon, 2018).

Poverty level is higher in the rural areas when compared to the urban areas. Most of the rural dwellers are small scale farmers that depend on agriculture for food and income. It has been documented that most of these small scale farmers have access to micro credit. Emefesi and Yusuf (2014) posited that micro credit plays a crucial role in agricultural development as it enable farmers, enjoy the advantages of economies of scale and venture into the use of technologies for optimum production. It has been effective in opening new economic opportunities for the rural farmers and increasing access to production resources (Abadi and Okugbe, 2016). According to Arifalo and Ayilaran (2012) micro credit financing has proven to be effective when it comes to poverty alleviation globally. It is of importance to plan towards achieving the sustainable development goal 1 of ending extreme poverty globally by 2030 .

It is in view of these that the study assessed the poverty status among the small scale farm household's micro credit users in Ekiti state. Specifically, the study described the socio economic characteristics of the respondents; identified the poverty status of the respondents and determined the factors influencing the poverty status of the small scale farm household's micro credit users in Ekiti state.

\section{MATERIALS AND METHODS}

Study area: This study was carried out in Ekiti state, Nigeria. The state lies within the tropics between Longitudes $4^{\circ} 45^{1}$ and $6^{\circ} 45^{1}$ East of the Greenwich meridian and latitudes $7^{\circ} 15^{1}$ and $8^{\circ} 5^{1}$ North of the Equator. The state experiences a typical tropical climate with two different seasons, raining season from April-October while the dry season is between November and March. The state shares boundary in the North with Kwara and Kogi states in the East and South with Ondo state and in the west with Osun state. The state has a population of about 2,384,212 which represents about $1.7 \%$ of the nation's total population with a covered land area of $6,353 \mathrm{~km}^{2}$ (NBS, 2008; NPC, 2006). The average annual rainfall is between 2000 and 2400 $\mathrm{mm}$ while the average annual temperature ranges between 20 and $27^{\circ} \mathrm{C}$. There are sixteen local government areas in the state.

Sampling technique and data analysis: A multi-stage sampling procedure was used to select the respondents for this study. The first stage involved random selection of five Local Government Areas (LGAs) out of the sixteen LGAs in the state. The second stage involved random selection of two communities from each of the selected LGAs. At the third stage, random selection of fifteen respondents from the selected communities was carried out. Thus, a total of 150 respondents were used for the study. A well-structured questionnaire and interview schedule were used to elicit information from the respondents. The data collected were analyzed with the use of descriptive statistics, Foster-Greer-Thorbecke (FGT) poverty indices and multivariate probit model.

\section{Model specification}

Foster-Greer-Thorbecke (FGT) poverty measures: This was used to evaluate the poverty status of the respondents.

$$
\mathrm{P}_{\propto}=\frac{1}{\mathrm{~N}} \sum_{\mathrm{i}=1}^{\mathrm{q}}\left[\frac{\psi-\mathrm{Y}_{\mathrm{i}}}{\psi}\right]^{\propto}
$$

Where:

$\mathrm{P} \quad$ : Poverty index

$\mathrm{N}$ : The size of the population

$\psi-Y_{i}$ : The gap between the poverty line and the income of each farmer

$\psi \quad$ : Poverty line

q : The number of individuals below the poverty line

a : Degree of concern for the depth of poverty (it takes the value of 0,1 and 2)

$\mathrm{Y}_{\mathrm{i}} \quad$ : Per capita household annual income

Incidence of poverty: When there is no any aversion to poverty, Eq. 1 becomes the incidence of poverty which can be represented as:

$$
\mathrm{P}_{0}=\frac{1}{\mathrm{~N}} \sum_{\mathrm{i}=1}^{\mathrm{q}}\left[\frac{\psi-\mathrm{Y}_{\mathrm{i}}}{\psi}\right]^{0}
$$


where, $\mathrm{P}_{0}=$ Incidence of poverty. This is the head count ratio or the prevalence of poverty. It indicated the proportion below the poverty line. The higher the index, the greater the proportion of households that are poor. Other variables are as earlier defined.

Poverty depth: When there is uniform concern about the depth of poverty, that $\alpha=1$, then Eq. 1 becomes:

$$
\mathrm{P}_{1}=\frac{1}{\mathrm{~N}} \sum_{\mathrm{i}=1}^{\mathrm{q}}\left[\frac{\psi-\mathrm{Y}_{\mathrm{i}}}{\psi}\right]^{1}
$$

where, $\mathrm{P}_{1}$ is the poverty depth. Theother variables are as earlier defined. This $\left(\mathrm{P}_{1}\right)$ index measures the depth of poverty called poverty gap. It is only sensitive to the average poor. However, it shows the amount that would be required to bring the average poor to the poverty line.

Severity measure: Severity of poverty this is when $\alpha=2$, the Eq. 1 becomes:

$$
\mathrm{P}_{2}=\frac{1}{\mathrm{~N}} \sum_{\mathrm{i}=1}^{\mathrm{q}}\left[\frac{\psi-\mathrm{Y}_{\mathrm{i}}}{\psi}\right]^{2}
$$

where, $\mathrm{P}_{2}$ is the poverty severity. The other variables are as earlier defined. This means that the further away a person is from the poverty line, the higher the value of index $\left(\mathrm{P}_{1}\right)$. Therefore, the higher the value of this index, the more severe the poverty.

Multivariate probit model: This was used to determine the factors influencing the poverty status of the small scale farmers in Ekiti state, Nigeria. The general probit model is specified as follows:

$$
\operatorname{Pr}\left(Y_{i}\right)=f\left(\beta_{0}+X_{i} \beta_{i}+e_{i}\right)
$$

Where:

$\mathrm{P}_{\mathrm{r}}$ : Probability function

$\mathrm{X}_{\mathrm{i}}: \mathrm{n} \mathrm{x} \mathrm{k}$ matrix of explanatory variables

$\beta_{\mathrm{i}}: \mathrm{k} \times \mathrm{l}$ vector of parameter to be estimated

$Y_{i}$ : Dependent variable below:

The specific probit model for this study is stated as

$$
Y=\beta_{0}+\beta_{1} X_{1}+\beta_{2} X_{2}+\beta_{3} X_{3}+\beta_{4} X_{4}+\beta_{5} X_{5}+, \ldots,+\beta_{12} X_{12}+e_{i}
$$

Where:

Y : Dichotomous dependent variable measuring the poverty status of the respondents (non poor 1 and 0 for poor). The independent variables are as follow:

$\mathrm{X}_{1}$ : Household head sex. It is a dummy variable. The variable will take the value of 1 if male and 0 if female
$\mathrm{X}_{2}$ : Age of the respondent (years)

$\mathrm{X}_{3}$ : Marital status. This shows the marital status of the household head. It takes the value of one if married and (0) if otherwise

$\mathrm{X}_{4}$ : Educational level of the farmer (years)

$\mathrm{X}_{5}$ : Household size. This is the total number of persons within the household. In this study, a household is regarded as people who shared a common source of food

$\mathrm{X}_{6}$ : Membership of socio-economic organization. This measured membership of household's head of any socio-economic organization in their environment (1 for membership; 0 otherwise)

$\mathrm{X}_{7}$ : Household income measured in Naira

$\mathrm{X}_{8}$ : Farm size measured (ha)

$\mathrm{X}_{9}$ : Amount of microcredit collected in Naira

$\mathrm{e}_{\mathrm{i}}:$ Error term

Poverty line determination: Relative poverty line was constructed for this study to classify the households into poor and non-poor. Income approach was used to derive the poverty line. This stands as a proxy for the standard of living. The poverty line is calculated as: the Total Household Annual Income (THHAI) divided by Household Size (HOSI) to give the Per Capita Household Annual Income (PCHHAI), that is:

$$
\text { PCHHAI }=\frac{\text { Total household annualincome }}{\text { household size }}
$$

Mean Per Capital Household Annual Income (MPCHHAI) is calculated by:

$$
\text { MPCHHAI }=\frac{\text { Total per capita household annual income }}{\text { Total No. of household }}
$$

Using Mean Per Capita Household Annual Income (MPCHHAI) as poverty line, the households were classified as:

- The non-poor-those with per capita household annual income greater than or equal to the poverty line

- The poor-households with PCHHAI less than poverty lines

\section{RESULTS AND DISCUSSION}

The result in Table 1 reveals the socio-economic characteristics of the respondents in the study area. Less than half $(40 \%)$ of the respondents were in the age range of $41-50$ years while $31.33 \%$ of them fell with in the age range of $31-40$ years. Also, $18 \%$ were between the age of 51 and 60 years while $7.34 \%$ of them were above 60 years and the remaining $3.33 \%$ were $<31$ years Table 1 . The 
Int. Business Manage., 13 (9): 415-422, 2019

Table 1: Socio-economic characteristics of the respondents

\begin{tabular}{|c|c|c|c|}
\hline Variables & Frequency & Percentage & Mean \\
\hline \multicolumn{4}{|l|}{$\overline{\text { Age (year) }}$} \\
\hline$<31$ & 5 & 3.33 & \multirow[t]{8}{*}{46} \\
\hline $31-40$ & 47 & 31.33 & \\
\hline $41-50$ & 60 & 40.00 & \\
\hline $51-60$ & 27 & 18.00 & \\
\hline Above 60 & 11 & 7.34 & \\
\hline \multirow{4}{*}{\multicolumn{4}{|c|}{$\begin{array}{l}\text { Sex } \\
\text { Male } \\
\text { Female } \\
\text { Marital status }\end{array}$}} \\
\hline & & & \\
\hline & & & \\
\hline & & & \\
\hline \multicolumn{4}{|l|}{ Married } \\
\hline Single & 9 & 6.00 & \\
\hline Widow & 6 & 4.00 & \\
\hline Widower & 3 & 2.00 & \\
\hline \multicolumn{4}{|l|}{ Household size } \\
\hline $1-3$ & 16 & 10.67 & \multirow[t]{7}{*}{6} \\
\hline $4-6$ & 134 & 89.33 & \\
\hline \multirow{6}{*}{\multicolumn{4}{|c|}{$\begin{array}{l}\text { Level of education } \\
\text { No formal education } \\
\text { Primary education } \\
\text { Secondary education } \\
\text { Tertiary education } \\
\text { Household annual income (N) }\end{array}$}} \\
\hline & & & \\
\hline & & & \\
\hline & & & \\
\hline & & & \\
\hline & & & \\
\hline$<200,001.00$ & 20 & 13.33 & \multirow[t]{5}{*}{$\mathrm{N} 224,846$} \\
\hline $200,001.00-500,000.00$ & 111 & 74.00 & \\
\hline $500,001.00-1,000,000.00$ & 14 & 9.33 & \\
\hline $1,000,001.00-1,500,000.00$ & 3 & 2.00 & \\
\hline More than $1,500,000.00$ & 2 & 1.34 & \\
\hline \multicolumn{4}{|l|}{ Farm size (ha) } \\
\hline$<1$ & 33 & 22.00 & \multirow[t]{3}{*}{2} \\
\hline $1-2$ & 107 & 71.33 & \\
\hline Above 2 & 10 & 6.67 & \\
\hline \multicolumn{4}{|c|}{ Type of farming system practice } \\
\hline Crop production & 78 & 52.00 & \\
\hline Livestock production & 72 & 48.00 & \\
\hline \multicolumn{4}{|l|}{ Nature of farming } \\
\hline Full-time & 36 & 24.00 & \\
\hline Part-time & 114 & 76.00 & \\
\hline \multicolumn{4}{|l|}{ Farming experience (years) } \\
\hline $1-10$ & 45 & 30.00 & \multirow[t]{4}{*}{18} \\
\hline $11-20$ & 41 & 27.33 & \\
\hline $21-30$ & 53 & 35.33 & \\
\hline More than 30 & 11 & 7.34 & \\
\hline Sources of labour & & & \\
\hline Communal labour & 9 & 6.00 & \\
\hline Family labour & 27 & 18.00 & \\
\hline Hired labour & 50 & 33.34 & \\
\hline Mechanized labour & 20 & 13.33 & \\
\hline Both family and hired labour & 44 & 29.33 & \\
\hline Membership of cooperative & & & \\
\hline Yes & 113 & 75.33 & \\
\hline No & 37 & 24.67 & \\
\hline Main sources of credit & & & \\
\hline Esusu & 11 & 7.33 & \\
\hline Relatives and friends & 9 & 6.00 & \\
\hline Micro credit agency & 107 & 71.33 & \\
\hline Banks & 23 & 15.34 & \\
\hline Loan applied for and grante & & & \\
\hline$<200,001.00$ & 71 & 47.33 & $427,950.000$ \\
\hline $200,001.00-500,000.00$ & 57 & 38.00 & \\
\hline $500,001.00-1,000,000.00$ & 18 & 12.00 & \\
\hline More than $1,000,000.00$ & 4 & 2.67 & \\
\hline Amount spent on farm activ & & & \\
\hline$<100,001$ & 69 & 46.00 & $161,755.00$ \\
\hline $100,001-300,000$ & 68 & 45.33 & \\
\hline
\end{tabular}


Int. Business Manage., 13 (9): 415-422, 2019

Table 1: Continue

\begin{tabular}{|c|c|c|c|}
\hline Variables & Frequency & Percentage & Mean \\
\hline $300,001-500,000$ & 9 & 6.00 & \\
\hline More than 500,000 & 4 & 2.67 & \\
\hline \multicolumn{4}{|l|}{ Credit term } \\
\hline Long term & 36 & 24.00 & \\
\hline Medium term & 15 & 10.00 & \\
\hline Short term & 99 & 66.00 & \\
\hline
\end{tabular}

Table 2: Main challenges encountered in accessing microcredit facilities

\begin{tabular}{lll}
\hline Main challenges & Frequency & Percentage \\
\hline Lack of collateral & & \\
Security & 72 & 48.00 \\
Delay in disbursement & 38 & 25.33 \\
High rate of interest & 15 & 10.00 \\
Bureaucratic bottleneck & 25 & 16.67 \\
Total & 150 & 100 \\
\hline
\end{tabular}

mean age of the respondents was 46 years and this implies that the small scale farmers in the study area are still within the active and productive age range. Most (78.67\%) of the respondents were male while $21.33 \%$ of them were female. This shows that men are more into farming than their women counterparts in the study area. The majority (88\%) of them were married with average household size of 6 personsand this connotes a large household size among the respondents. In addition, $85.33 \%$ of them had access to formal education. This will assist the farmers to read and understand materials on agricultural production.

The average farm size of the respondents was 2 ha and their average farm income was N224,846.00 per annum while $76 \%$ of them were into farming operation on part-time basis. The majority (52\%) were crop farmers while $48 \%$ were into livestock production. The average year of farming experience was 18 years and the common types of labour used were family and hired labour. Hence, most $(75.33 \%)$ of them belonged to one or more forms of cooperative society and this is their source of information on microcredit.

The result in Table 1 also reveals that most (71.33\%) of the respondents indicated that micro credit agency was the main source of the credit facility accessible to them while $15.34 \%$ of them indicated banks as the sources of loan. Also, $7.33 \%$ indicated that Esusu was the main source of their micro credit and $6 \%$ of them showed that relatives and friends were the sources of their micro credit. About $47.33 \%$ of the respondents indicated that they applied for less than N200,001 and it was granted while $38 \%$ of them applied for loan between N200,001 and N500,000 and it was granted. Only few (14.67\%) of them applied for and granted more than N500,000. The average loan applied for and granted was N427,950. However, $46 \%$ of them spent less than N100,001 on their farming activities out of the loan collected, $45.33 \%$ spent between $\mathrm{N} 100,001$ and $\mathrm{N} 300,000$ on their farming activities and only few $(8.67 \%)$ of them spent more than
$\mathrm{N} 300,000$ on their farming activities and N161,755 was the average amount spent on farming activities by the respondents out of the average of N427,950 applied for and granted. More than half $(66 \%)$ of the respondents indicated that the micro credit granted was on short term basis while only $24 \%$ of them were granted for long term.

Main challenges encountered by farmers in accessing micro credit: Table 2 shows the main challenges encountered by the respondents in micro credit accessibility. Almost half (48\%) of the respondents indicated that lack of collateral security was the main challenge encountered in accessing credit facilities while $25.33 \%$ of them indicated delay in disbursement of fund was the main challenge encountered by them. Also, $16.67 \%$ of them indicated that bureaucracy in micro credit accessibility was the main challenge encountered and only $10 \%$ of them indicated high rate of interest as the majorchallenge encountered by them. This corroborates the findings of Emefesi and Yusuf (2014) that late release of fund, bureaucratic bottlenecks, collateral problem, lack of bank of agriculture in the communities, inadequate fund, short term repayment period and sentiment are the challenges encountered by the farmers in accessing loans. Ayegba and Ikani (2013) opined that late approval of loan and short repayment period are the major constraints encountered by the farmers.

Poverty status of the respondents: The poverty status was determined by fitting the poverty line of N45,905 to the sample data with respect to per capita household annual income. Table 3 shows the extent of poverty among the households. The result indicates that the majority, $73.33 \%$ of the households were poor, each person earning less than N45,905 annually while $26.67 \%$ were non poor. This implies that most of the small scale farmers in the study area are poor. It shows that, majority of the sampled small scale farming households microcredit users in the study area live below the average income.

Foster-greer-thorbecke measures of poverty: In order to corroborate or refute the result in Table 4, Foster-Greer-Thorbecke (FGT) indiceswere equally used. Mean Per Capita Household Annual Income (MPCHHAI) of N45,905 was used as poverty line. Table 4 reveals that the poverty incidence $\left(\mathrm{P}_{\mathrm{o}}\right)$ was 0.7333 implying that in the 
study area, $73.33 \%$ were poor among the small scale farming households. The poverty depth $\left(\mathrm{P}_{1}\right)$ of 0.1432 indicated that the average income of the poor in the state was $14 \%$ less than the poverty line while the severity of the poverty $\left(\mathrm{P}_{2}\right)$ of 0.0470 showed that the incomes of the poor were very close to the poverty line. Hence, little effort is needed to move them to the poverty line. The finding is in line with that of Oluwatusin (2010) that most of the farm households in Ekiti state are poor.

Parameter estimation of the poverty status of the respondents: Probit regression analysis was used to determine the factors influencing the poverty status of the small scale farm household's micro credit users in Ekiti state, Nigeria. The results were presented in Table 5. The likelihood estimate of the probit model indicated that Chi-square $\left(\chi^{2}\right)$ statistic of 121.22 was significant at $1 \%$ level of significance, suggesting that the model showed a good fit to the data.

Sex of the household head had positive and significant (1\%) relationship with the poverty status. This implies that, poverty is not rampant among the small scale farm households headed by men. That is poverty level is high among the small scale female headed farm households in the study area. Also, age of the household head was positively and significantly $(10 \%)$ related to the poverty status of the farm households. This implies that as the household head grows old the probability of the household being poor reduces. This is contrary to the findings of Igbalajobi, Fatuase and Ajibefun that as respondent gets older, the probability of being poor increases.

Marital status had positive but not significant relationship with the poverty status of the households. This shows that the probability of the household being poor is low among the households headed by scale farmers. Educational level was positively and significantly $(5 \%)$ related to poverty status. This indicates that as the educational level increases, the probability of being poor decreases and vice versa. Household size had positive and significant $(1 \%)$ relationship with the household poverty status. This signifies that the more the household size the less the probability of being poor. This may happen when most of the household members are engaged in paid economic activities.

Moreover, membership of socio-economic organization was negatively and significantly (10\%) related to poverty status. This is contrary to expectation. The result implies that the probability of being poor is higher among those that are members than non-members of socio-economic organizations. Household income showed a positive and significant $(10 \%)$ relationship with the poverty status of the small scale farm households. This indicates that as the household income increases the probability of being poor decreases. This supports the a priori expectation. The welfare of farm households is expected to improve with more income.

Also, farm size displayed a non-significant positive relationship with the household poverty status. It shows that as farmers farm size increases, the likelihood of not being poor increases. This is possible because the more the farm land cultivated, the more the income from the sales of agricultural outputs. More also, the amount of micro credit collected had a positive and significant $(1 \%)$ relationship with the poverty status of the small scale farm households. This implies that micro credit increases the chances of not being poor. The main determinants of poverty status among the small scale farm households credit users were, sex, age, educational level, household size, membership of socio-economic organization, household income and amount of micro credit collected.

Table 3: Poverty status of the respondents

\begin{tabular}{lll}
\hline Poverty status & Frequency & Percentage \\
\hline Poor & 110 & 73.33 \\
Non poor & 40 & 26.67 \\
\hline
\end{tabular}

Table 4: Foster-Greer-Thorbecke poverty indices

\begin{tabular}{llll}
\hline Variable & $\mathrm{P}_{0}$ & $\mathrm{P}_{1}$ & $\mathrm{P}_{2}$ \\
\hline Poverty status & 0.7333 & 0.1432 & 0.0470 \\
\hline $\mathrm{P}_{0}$ Povity
\end{tabular}

$\mathrm{P}_{0}$ : Poverty incidence; $\mathrm{P}_{1}$ : Poverty depth; $\mathrm{P}_{2}$ : Poverty severity

Table 5: Probit model result of factors influencing poverty status

\begin{tabular}{lll}
\hline Variable name & Coefficient & SE \\
\hline Constant & -3.0573 & 1.9697 \\
Sex & $0.8800^{* * *}$ & 0.2500 \\
Age & $0.0379 *$ & 0.0227 \\
Marital status & 0.9337 & 0.6166 \\
Educational level & $0.0131^{* *}$ & 0.0005 \\
Household size & $0.4308^{* * *}$ & 0.1242 \\
Membership of socio-economic organization & $-0.1962 *$ & 1.67 \\
Household income & $0.2356^{*}$ & 0.1032 \\
Farm size & 0.0821 & 0.1324 \\
Amount of microcredit collected & $0.0348^{* * *}$ & 0.0812 \\
No. of observation & 150 & 0.0102 \\
Log likelihood & -14.616 & 3.47 \\
Pseudo $\mathrm{R}^{2}$ & 0.5231 & 1.78 \\
Prob $>\chi^{2}$ & 0.0002 & 1.01 \\
LR $\chi^{2}(9)$ & 121.22 & 3.41 \\
$* * * * *$ and $*$ represent 1,5 and $10 \%$ levels of significance, respectively & \\
\end{tabular}




\section{CONCLUSION}

This study assessed the poverty status among the small scale farm household's micro credit users in Ekiti state, Nigeria. A multi-stage sampling method was used to select 150 small scale farm households micro credit users while the data collected were subjected to descriptive statistics, Foster-Greer-Thorbecke (FGT) poverty measures and multivariate probit model analyses. The study discovered that the mean age of the household heads was 46 years and the majority $(78.67 \%)$ were males. Most (88\%) of the households heads were married with average household size of 6 persons while $85.33 \%$ of them had access to formal education. The average farm size of the respondents was 2 ha with average farm household income of $\mathrm{N} 224,846.00$ per annum. In addition, $76 \%$ of them were into farming operation on part-time basis. The majority (52\%) were crop farmers with average farming experience of 18 years and $75.33 \%$ were members of cooperative societies.

The main source of micro credit available to $71.33 \%$ of the respondents was micro credit agency in the state and the average loan applied for and granted was N427,950 while N161,755 was the average amount spent on farming activities. Most (66\%) of the respondents were granted short term micro credit. The main challenge encountered in accessing micro credit facilities by $48 \%$ (most) of respondents was lack of collateral security. Mean Per Capita Household Annual Income (MPCHHAI) of N45,905 was used as poverty line in determining the respondents poverty status. It was revealed that $73.33 \%$ (Poverty incidence $\left(\mathrm{P}_{\mathrm{o}}\right)$ ) of the respondents were poor while the average income of the poor in the state was $14.32 \%$ (poverty depth $\left(\mathrm{P}_{1}\right)$ ) less than the poverty line. The severity of poverty $\left(\mathrm{P}_{2}\right)$ was 0.047 . All the independent variables included in the probit model affected poverty status positively with exception of membership of socio-economic organization. The main factors influencing the poverty status of the respondents were, sex, age, educational level, household size, membership of socio-economic organization, household income and amount of micro credit collected.

Despite the fact that the respondents are micro credit users, most of them are still poor. This may be due to the amount of micro credit applied for by the respondents and granted by various sources of micro credit. Problems such as lack of collateral security, delay in disbursement, high rate of interest and bureaucratic bottleneck might have led to the small amount of micro credit applied for. Also the diversion of high percent of the micro credit collected by farmers to other uses apart from agricultural production might have been another reason why most of them are poor.

\section{RECOMMENDATIONS}

The following recommendations are made based on the findings of this study: it has been observed that education played a positive role in poverty reduction. Farmers should be encouraged by the governments and non-governmental organizations to improve on their educational level in order to reduce the incidence of poverty among them. Size of micro credit given to the farmers by micro credit agency should be improved upon in order to boost agricultural production and alleviate poverty among the small scale farmers. Also, household income will be increased when more micro credit is made available to the farmers. Diversion of micro credit meant for agricultural production should be discouraged among the farmers through effective monitoring of the use of micro credit collected. There should be reduction in the interest rate on micro credit given to the farmers. One digit interest rate should be enforced by the Central Bank of Nigeria (CBN) on the micro credit agencies. This will go a long way in addressing the issue of high poverty rate among the small scale farm households. The CBN should look into the micro credit repayment periods and structures. In order to encourage investment over longer time horizons which lead to longer-term profit and growth in agriculture. Short-term micro credit to farmers should be discouraged. In order to reduce the problem of lack of collateral security among the small scale farm households, farmers should be sensitized on the importance of cooperative society and the Agricultural Credit Guarantee Scheme Fund (ACGSF). Also the problem of late disbursement of micro credit to farmers should be addressed because this could lead to diversion and misuse of micro credit.

\section{REFERENCES}

Abadi, Q.R. and R.R. Okugbe, 2016. An assessment of impact of micro-credit scheme on local farmers in Nigeria. World Acad. Res. Sociology Anthropol., 2: 85-88.

Anderson, J., C. Marita, D. Musiime and M. Thiam, 2017. National survey and segmentation of smallholder households in Nigeria: Understanding their demand for financial, agricultural and digital solutions. Consultative Group to Assist the Poor, $\mathrm{W}$ a s h i n g to n D C., U S A. https://www.academia.edu/35066364/National_Sur vey_and_Segmentation_of_Smallholder_Househol ds_in_Nigeria_Understanding_Their_Demand_for _Financial_Agricultural_and_Digital_Solutions 
Arifalo, S.F. and C.I. Ayilaran, 2012. Effects of micro-credit scheme on agricultural production among members of farmer's development union, Oyo State, Nigeria. Niger. J. Agric. Econ., 3: 59-68.

Ayegba, O. and D.I. Ikani, 2013. An impact assessment of agricultural credit on rural farmers in Nigeria. Res. J. Finance Accounting, 4: 80-89.

Emefesi, B. and B. Yusuf, 2014. Access and impact of micro credit on poverty alleviation among farmers in Kirfi local government area of Bauchi State. IOSR. J. Agric. Vet. Sci. (IOSR-JAVS.), 7: 30-35.

NBS, 2008. Annual Abstract of Statistics. National Bureau of Statistics, Abuja.

NPC., 2006. National Census Data for Nigeria. National Population Commission, Abuja, Nigeria,
Oluwatusin, F.M., 2010. Poverty Status Among Households in Nigeria. VDM Publishing House Ltd., Mauritius, ISBN: 9783639319613, Pages: 232.

SC., 2019. Nigeria: Distribution of Gross Domestic Product (GDP) across economic sectors from 2008 to 2018. Statista Company, Hamburg, Germany. https://www.statista.com/statistics/382311/nigeriagdp-distribution-across-economic-sectors/

Solomon, E., 2018. Economic analysis of poverty status of small-scale farmers in Bayelsa State, Nigeria. Invest. Agric. Curr. Res., 4: 614-619.

World Bank, 2004. World development report 2000/2001: Affecting poverty. World Bank, Washington DC., USA. 